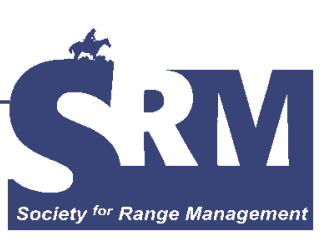

\title{
Changing Western Landscapes, Debt, and Oil: A Perspective
}

\section{Rapidly rising consumer debt, a real estate bubble, and depletion of world oil reserves could greatly affect western rangelands and ranching.}

\section{By Jerry L. Holechek}

\section{Introduction}

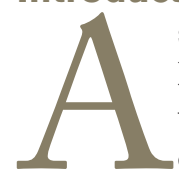

s a lover of rangelands, ranching, and wildlife, I have deep feelings of consternation over the rapid urban and exurban development now occurring on many landscapes in the western United States. I often find myself wondering if and when this trend might slow down and stabilize. During the course of the last 5 years I have traveled rather extensively in the western and central United States, Europe, Russia, and Ukraine to observe farming, ranching, forestry, wildlife management, and other land use practices. In addition, I have been reading about national problems such as land fragmentation, government debt, consumer debt, changing demographics, rising oil prices, climatic change, and the possible bubble in real estate. I will attempt to look into the future evaluating how these forces might affect rangeland landscapes and ranching.

\section{Land Hunger and Land Availability}

Various times I have polled students in my range management classes regarding how they hope to live after they initiate their careers. Invariably I will find 9 out of 10 students aspire to a life in the western United States on a 10-acre or more tract of land. Over the next 60 years it is expected that the human population of the United States will double from 290 to 600 million people. If one-quarter of these additional

This article has been peer reviewed. people (75 million) lived on 10-acre tracts, 750 million acres of rangeland, or $68 \%$ of the rangeland in the United States, would be lost to non-ranching uses (Figure 1).

A major question is how much the privately held rangeland will be lost to development. I believe we may be approaching a point where the amount of rangeland that will undergo subdivision within the 10 contiguous western states will slow down. One major reason is that much of the private land that can be subdivided is being subdivided. Many of the

\section{Land Area and Ownership in the United States}

The United States has about 2.3 billion acres and one-half is considered to be rangeland. The total amount of land controlled by the federal government is 654 million acres or $28 \%$. The Bureau of Land Management controls 264 million acres while the Forest Service controls 192 million acres. When Alaska is removed, the amount of federal rangeland in the 10 contiguous western states is near 300 million acres. Roughly 180 million acres is in private ownership. Some estimates indicate that 45 million acres have been converted into other uses so far.

subdivisions are not mature and many more parcels can be sold. There is a more subtle trend to further subdivide larger ranchettes into smaller ranchettes.

Conservation easements are becoming a popular way to protect privately owned rangeland. ${ }^{1}$ I am hopeful that over 


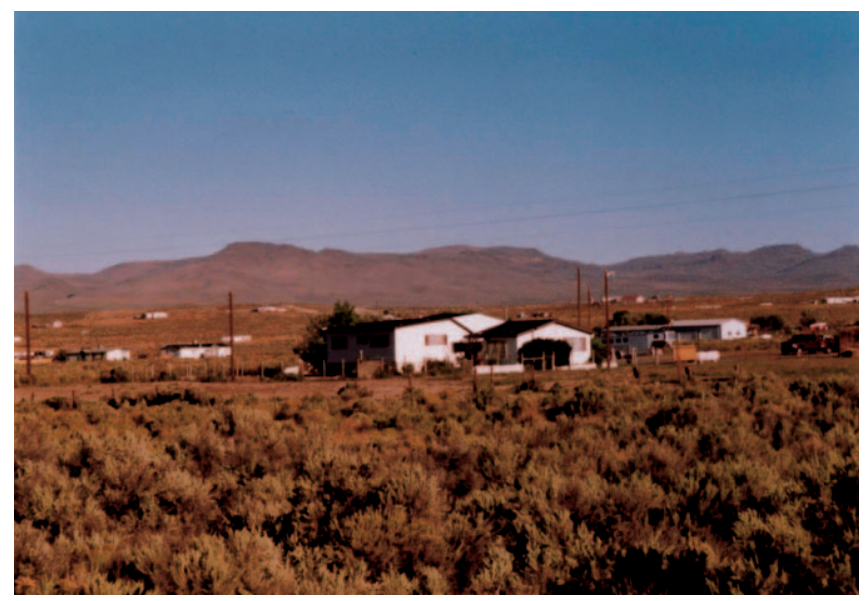

Figure 1. Rangeland that has been subdivided into 10-acre parcels in northwestern New Mexico. This pattern of land use requires high amounts of infrastructure per individual home and typically involves long commutes between work and home.

the next 20 years at least $50 \%$ of the remaining privately held rangelands will be protected by conservation easements, federal government incentives, and private initiatives.

In New Mexico, where I live, the financial effectiveness of ranch subdivision is changing. Developers are now being required to sustain more of the costs of infrastructure such as roads, water, electricity, and waste disposal. Taxes assigned to the developers and buyers are increasing as counties become overwhelmed with costs for new roads, road improvements, road maintenance, water provision, and waste disposal. Regulations and restrictions on ranch subdivisions are being increased. These same trends are occurring to varying degrees in other western states.

Without question the baby boom generation born between 1946 and 1964 has driven the unprecedented demand for rangeland parcels as home sites and ranchettes over the last 15 years. Baby boomers will begin retiring in big numbers in 2008. However, many have already purchased their retirement homes in the western states. Nevertheless their incremental retirement between 2008 and 2026 could keep demand high for ranchettes for another 4 to 10 years. On the other hand they may soon run out of money. This I will discuss.

\section{A Speculative Bubble in Real Estate}

There is growing concern about a nationwide speculative bubble in real estate. ${ }^{2}$ In some parts of the West a quarter of the new homes are vacant. They have been built for quick sale to take advantage of escalating home prices. It has become a common practice for homeowners to take out home equity loans to finance the purchase of second and even third homes. No or low down payment requirements (only 5\%), low interest rates, and variable rate loans where the purchaser pays only interest for the first one to three years have made it easy to speculate in real estate. Las Cruces, New Mexico, and Pagosa Springs, Colorado, are examples with which I am familiar where lots alone have appreciated 30\%-40\% per year during the 2002-2005 period. In several remote pinyon juniper areas of western New Mexico rangeland valued at $\$ 50$ an acre for grazing is now selling at $\$ 1000$ or more an acre for 10- to 20-acre tracts. These deals typically involve high leverage and low occupancy.

\section{Rising Living Costs on Ranchettes}

In New Mexico property taxes for owners of ranchettes have averaged about $30 \%-40 \%$ of those for town homeowners. On one hand the ranchette owners receive fewer services from the county than town homeowners. Garbage disposal, sewage disposal, street maintenance, and provision of domestic water are some of the services that town homeowners receive that are not provided to ranchette owners. On the other hand ranchette homes compared to suburban homes require a much higher amount of infrastructure such as roads, electricity and communication wiring per home. Counties are finding it necessary to raise taxes on rural homeowners as both the number of dwellings and demand for services increases.

\section{Economic Importance of Construction}

I do think it is important to recognize that construction, particularly home construction, has played a critical role in rescuing the US economy from the stock market crash and economic slowdown in the 2000-2002 period. Nationwide construction accounted for about $40 \%$ of economic activity in 2004. Many counties in the western United States would be in deep financial trouble without the boom in demand for rangeland parcels as ranchettes and home sites. This boom has created many new jobs in western counties that were faltering from loss of jobs due to the banning of logging on national forest lands to protect spotted owl habitat. Rising ranching costs, drought, and increased regulation on federal grazing lands have made the last 10 years a very difficult time for western ranchers. Demand for ranchettes and home sites has allowed many ranchers to stay in business through liquidation of small portions of their property to pay off debt and generate income. It is quite rational and wise for financially stressed ranchers to sell rangeland to developers at prices 5 to 15 times fair value for grazing.

\section{Debt Levels}

Debt levels of both citizens and the US government are at unprecedented levels and rapidly rising. ${ }^{3}$ Many econo-

\section{Federal Debt of the United States}

Presently the US government owes about $\$ 6$ trillion which is $\$ 20,000$ per person. Consumer debt is about $\$ 8,000$ for every man, woman, and child. Mortgage debt adds on another $\$ 24,000$ which adds up to a total of $\$ 52,000$ per capita. These figures do not take into account future unfunded liabilities owed by the federal government to itself for social security, Medicare, and Medicaid. 
mists worry that growing debt levels in the United States at some point will cause a major rise in interest rates and lead to a severe recession or depression. ${ }^{3}$ These economists often point out that it takes more and more expansion of credit to achieve the same level of economic growth in each successive business cycle. During the past 20 years several books have been written projecting doom and gloom if the US government and people did not reverse their excessive borrowing and pay off some of their debt. However, these dark prophesies have been unfulfilled and there have been no serious recessions since 1982. The 1983-2005 period has been the longest run of prosperity in the 220-year history of the United States.

From 1982 through 2005 the official debt of the US government grew from $\$ 1$ trillion to $\$ 6$ trillion. ${ }^{3}$ What this means is during the past 23 years the federal government on average has annually spent about $22 \%$ more than its revenues. American consumers in this same period have increased their debt about $2 \%$ per year. Without question all this spending has kept the economy much stronger than if the government and people had balanced their books.

Another worry is that approximately $40 \%$ of US federal debt is held by foreigners. ${ }^{3}$ Some of these creditors such as the Chinese and certain Muslim nations are not exactly friends and their motives are uncertain. If they ever quit buying US treasury securities - or worse, started cashing them in-it would wreak great havoc with the US economy by causing a rapid rise in interest rates and a devaluation of the dollar.

Continued prosperity and demand for western rangeland as home sites and ranchettes seems contingent on sustained credit and debt expansion in the United States. Both the federal government and financial institutions have been quite imaginative in finding ways to extend credit and finance debt. It does seem that at some point a threshold will be reached where debt levels become overwhelming and cause a major economic contraction.

\section{The Oil Factor}

During the past 50 years the trend has been for Americans to disperse from cities and towns into the suburbs and countryside. ${ }^{1}$ Both distance and time required for commutes between home and work have steadily increased. Cheap gasoline and the willingness of federal, state, and local governments to build more and better roads has reinforced this trend. Even interior western America is now characterized by several large semi-urbanized metropolitan areas involving 1,600 or more square miles where it is not uncommon for people to spend in excess of two hours a day driving between home and work. These areas include Phoenix, Arizona; Denver, Colorado; Dallas-Fort Worth, Texas; Salt Lake City, Utah; Las Vegas, Nevada; and Albuquerque, New Mexico. The trend towards urban sprawl is now accelerating at the very time when known world supplies of oil are in rapid decline. Some expert petroleum geologists believe that production of oil worldwide will peak within the next 2 to 5 years and then decline. ${ }^{4}$
Ten years ago the drastic increases in oil use by China, India, Russia, and several European countries was completely unforeseen. The United States imports 59\% of its oil mostly from Canada, Saudi Arabia, and Mexico. ${ }^{5}$ Spare oil capacity is considered to be primarily in the mideast with Saudi Arabia and Iraq holding the biggest reserves. However the magnitude of Saudi Arabian reserves is being seriously questioned. ${ }^{4}$ The widening gap between growing world oil demand and supply (growing more slowly or shrinking) may push the price of oil to over $\$ 100$ a barrel and gas prices at the pump to over $\$ 5$ a gallon within 3 to 5 years. A bigger concern is that oil shortages in the United States will cause a massive economic downturn and long waiting lines at the pump reminiscent of the 1970s. While there is uncertainty over the extent of world oil reserves and how fast demand will grow, it does seem prudent to encourage more conservation and efficiency in oil use in the United States. Oil matters because it has become the world's primary energy source and

\section{Global Demand for Oil is Rising}

The U.S. Department of Energy is now projecting that daily global demand for oil will grow by $50 \%$ during the next 20 years. ${ }^{5}$ The United States with $5 \%$ of the world's population uses $25 \%$ of world energy. China with $21 \%$ of the world's population uses $7.6 \%$ of the world's energy. Oil demand in China is growing about $14 \%$ per year compared to $1 \%$ per year in the United States. Worldwide oil demand is growing about $1.6 \%$ per year. This demand is expected to accelerate as China, Russia, India, Brazil, and Eastern Europe expand their economies.

is a critical component of plastic and many chemicals. Developing countries depend heavily on increased oil consumption to improve living conditions for their people.

A likely indirect impact of continuing increases in oil prices will be to increase the importance of rangelands for meat production. American agriculture is highly dependent on use of fossil fuels (oil) to power farm equipment, synthesize nitrogen fertilizer, and transport crops. ${ }^{6}$ Low oil prices have made it financially effective to raise cattle using high inputs of harvested forage and feed grains. At some point it is probable rising oil prices will force up grain prices and make it economically unfeasible to finish cattle for slaughter with a lengthy period of grain feeding. Cattle ranchers on western rangelands could experience higher profit margins if beef prices rise relative to production costs. Keep in mind that rangeland beef production involves lower fossil fuel inputs compared to when cattle are fed high quantities of harvested feed and grain. It requires about one third to one half less fossil energy (oil) to produce a pound of beef on rangeland compared to with harvested forage and grain..$^{7-9}$ Both human health benefits and improved pricing could make grass fattened beef more profitable in the future than in the past. Improved profitability of livestock 
would likely influence western ranchers to continue their livestock operations rather than subdivide their rangelands.

\section{Alternative Energy Sources}

Problems with immediate large-scale conversion to alternative energy sources to oil are discussed in some detail by Leeb and Leeb. ${ }^{4}$ They center around environmental contamination, difficulty in transport, difficulty in processing, lack of cost-effectiveness, high space requirement, and technological bottlenecks that need to be resolved. Other fossil fuels such as coal, natural gas, and oil shale have their individual drawbacks. With coal the primary problem is greenhouse gases, with natural gas it is difficulty in transport, and with oil shale it is difficulty in processing. Nuclear fission involves large expense in plant design and construction, terrorists and accidents can cause disastrous radioactive contamination, and radioactive waste creates major storage problems. Most of the better dam sites for hydroelectric power are being used and further dam building is not popular due to environmental problems. Presently cost-effectiveness is a problem for primary forms of solar energy, particularly photovoltaic

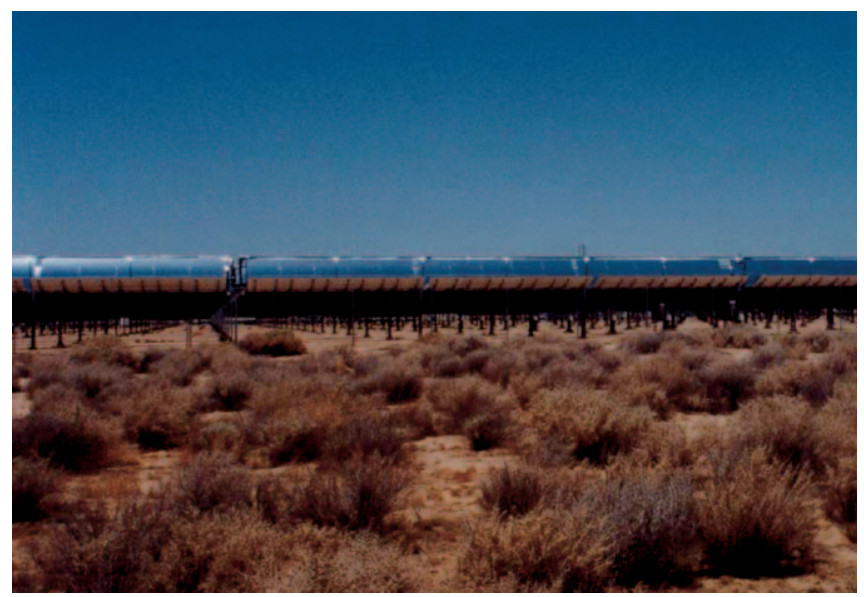

Figure 2. This solar energy system on southern California rangeland requires a large land area.

cells. The manufacturing process results in toxic wastes and requires high inputs of iron. Also photovoltaic cells need a lot of space (Figure 2).

Hydrogen offers the greatest hope for cheap, unlimited energy without pollution. The problem is that hydrogen does not occur in pure form. Basically to obtain hydrogen in pure form involves using energy from other sources to crush water to free up hydrogen molecules. This sounds rather simple but the drawback so far is expense. A low-cost, efficient way is needed to harness energy from the sun to crush water and free hydrogen. Next, big strides are needed in capability to store and transport hydrogen because it is very unstable. In summary, a hydrogen (fuel cell) based economy is probably several years down the road.

Wind offers the best hope to reduce reliance on fossil fuel in the short term. ${ }^{4}$ Sound, efficient technology to harness

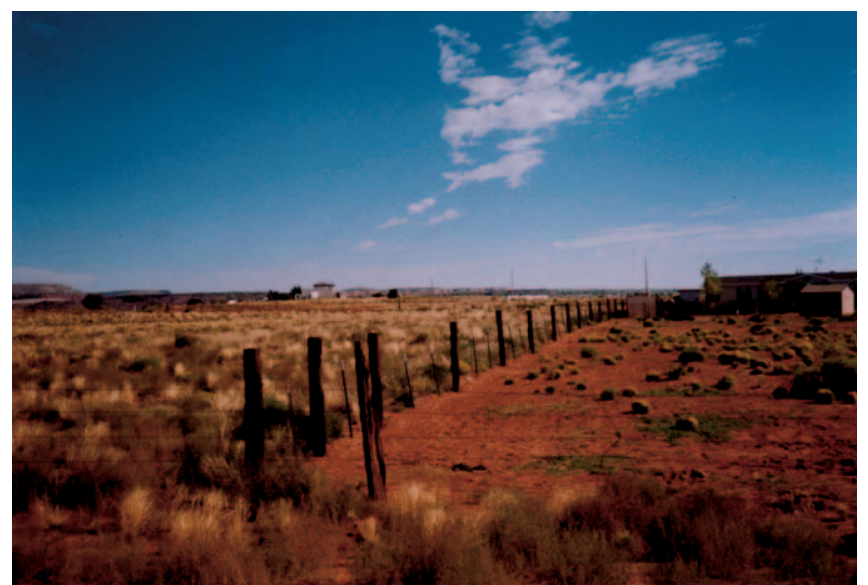

Figure 3. Rangelands fragmented into small parcels for homes often become severely degraded, support noxious weeds, and have low value for desirable native wildlife species based on Colorado research.

wind energy is now available. Wind energy is rapidly catching on in Europe and is starting to catch on in America. It seems certain wind ranching will become common and lucrative in the Great Plains and certain parts of the west. It is worth mentioning that North Dakota is the windiest state. Large areas supporting wind turbines will likely become part of western landscapes. I would rather see rangeland landscapes dominated by wind turbines than exurban sprawl.

\section{Energy Conservation}

Energy conservation in the United States played a big role in bringing down oil prices following the oil shock in $1981 .{ }^{4}$ Heavy investments in nuclear power and development of new oil fields were also important factors in the fall of oil prices during most of the 1980s. However, worldwide there have been no major new oil fields discovered for 30 years. It is expected known oil reserves will last 35-40 years. Under this scenario it would seem prudent to conserve existing oil to the extent possible. Unfortunately over the past 10 years just the opposite has been the case in the United States which uses more oil per capita and in total than any other country. The popularity of sport utility vehicles (notorious for poor fuel efficiency) and the trend for people to drive longer distances between home and work are major factors causing oil consumption to increase in the United States.

Conservation of oil and rangeland go hand in hand. Convincing people to live close to their work and in compact communities that facilitate mass transportation by bus, train, and car pooling would greatly reduce consumption of oil, clogged highways, and loss of rangeland to exurbanization. This village approach to living is widely practiced throughout Europe, Ukraine, and Russia.

Some other approaches to encouraging oil conservation would be to raise gasoline taxes, assign increased taxes to fuel inefficient vehicles, and provide tax incentives for people to live close to their work. Presently gasoline prices in the United States average about $\$ 2.93 /$ gallon compared to $\$ 5.40$ to $\$ 6.50 /$ gallon in European countries. It is my view that any 


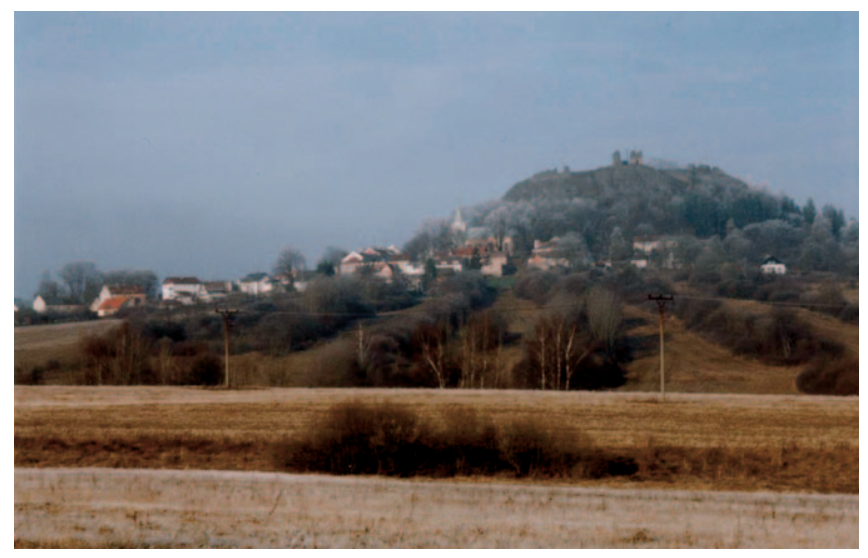

Figure 4. This compact village built on high ground in the Czech Republic facilitates mass transportation, is esthetically pleasing, and conserves land for agriculture, forestry, and wildlife.

increased taxes on gasoline in the United States should be used to fund research and development of alternative energy sources to fossil fuels. During the oil shock of 1981 gasoline near the equivalent of $\$ 3$ per gallon today finally induced Americans to become serious about energy conservation.

\section{Some Final Thoughts}

Natural landscapes across the western United States are being fragmented by division into small land parcels for second homes, retirement homes, and homes for people wanting to escape the higher living costs and stress of city life. A massive home construction boom is occurring throughout the United States that has been quite stimulatory to the economy. However, it is based on easy access to credit, low interest rates, and large-scale expansion of debt. The increased dispersal of people out of the cities and across rural landscapes is creating many problems such as loss of open space, loss of habitat for wildlife, loss of agricultural land, need for more and expanded highways, increased air contamination with greenhouse gases, and depletion of fossil fuel supplies (Figure 3). Even though Europe has nearly four times the human population density of the United States, most European countries have maintained a large amount of agricultural and forest lands by living in compact cities and villages (Figure 4). Per capita use of oil by Europeans varies from $40 \%-60 \%$ that of Americans ${ }^{10}$. In India per capita use of oil is only about $8 \%$ of that in America.

Little has been done to encourage Americans to conserve either open space or oil. If the present trends continue unchecked both rangelands and oil in the United States could be largely gone in 40 years. However, government and consumer debt and world shortage of oil may soon force major changes in American lifestyles. These changes could raise the values of rangelands for meat production, wildlife, water, open space, and esthetics and reduce their value as home sites and ranchettes.

It is my belief that most people do not understand the importance of rangelands in food production and for ecosystem services. The magnitude and implications of loss of rangelands has not been thoroughly researched and is poorly understood. I believe information, education, and government policies will be needed to slow and better manage conversion of rangelands into other uses. A national committee is needed to assess this problem and provide recommendations to the president and congress that will sustain rangelands in the future. Maintaining large areas of rangelands will be one of the great challenges in the 21st century.

Author is Professor of Range Science, Department of Animal and Range Sciences, New Mexico State University, Las Cruces, NM 88003, holechek@nmsu.edu. This paper was supported by the New Mexico Agricultural Experiment Station and was part of project 1-5-274170.

\section{References}

1. Maestas, J. D., R. L. Knight, and W. C. Gilgert. 2002. Cows, condos or neither: what's best for rangeland ecosystems. Rangelands 24(6):36-42.

2. Poniewozik, J. 2005. America's house party. Time Magazine: June 13:16-24.

3. Swanson, G. J. 2004. America the broke. New York, NY: Currency and Doubleday. $206 \mathrm{p}$.

4. Simmons, M. R. 2005. Twilight in the desert. New York, NY: John Wiley and Sons, Inc. $422 \mathrm{p}$.

5. Leeb, S., And D. Leeb. 2004. The oil factor. New York, NY: Warner Business Books. 220 p.

6. Holecheк, J. L., R. A. Cole, J. T. Fisher, and R. ValDEZ. 2003. Natural resources: Ecology, economics and policy. 2nd ed. Upper Saddle River, NJ: Prentice Hall. 761 p.

7. Соок, C. W. 1976. Cultural energy expended in range meat and fiber production. Journal of Range Management 29:268-271.

8. Соок, C. W. 1979. Meat production potential on rangelands. Journal of Soil and Water Conservation 34(4):168-171.

9. Сoок, C. W., A. H. Denham, E. T. Bartlett, and R. D. CHILD. 1976. Efficiency of converting nutrients and cultural energy in various feeding and grazing systems. Journal of Range Management 29:186-191.

10. Wachernagel, M., and W. Rees. 1996. Our ecological footprint. Gabriola Island, British Columbia, Canada: New Society Publishers. 166 p. 